\title{
STUDI SCANNING ELECTRON MICROSCOPY (SEM) UNTUK KARAKTERISASI PROSES OXIDASI PADUAN ZIRKONIUM
}

\author{
Agus Sujatno, Rohmad Salam, Bandriyana, Arbi Dimyati \\ Pusat Sains dan Teknologi Bahan Maju, PSTBM-BATAN \\ Email: a.sujatno@gmail.com
}

\begin{abstract}
ABSTRAK
STUDI SCANNING ELEKTRON MICROSCOPY (SEM) UNTUK KARAKTERISASI PROSES OXIDASI PADUAN ZIRKONIUM. Studi analisis Scanning Electron Microscopy (SEM) telah dilakukan untuk mengkarakterisasi struktur mikro dan lapisan oksida paduan zirkonium, bahan yang prospektif digunakan sebagai material kelongsong bahan bakar reaktor nuklir generasi ke IV dan struktur reaktor fusi modern. Tujuan penelitian adalah guna mendapatkan informasi yang detil dan akurat yang diperlukan untuk mendukung analisis ketahanan korosi paduan zirkonium yang disebabkan oleh proses oksidasi suhu tinggi dengan menggunakan berbagai metode analisis pada SEM. Sampel uji yang digunakan adalah ingot paduan zirkonium ZrNbMoGe setelah tes oksidasi dalam Mass Suspension Balance (MSB) pada temperatur 500 dan $700{ }^{\circ} \mathrm{C}$ masing-masing selama 5 jam. Komposisi unsur dalam sampel paduan adalah 96,9 \% Zr, 2,5 \% Nb, 0,5 $\%$ Mo dan 0,1 \%Ge. Pengujian SEM dilakukan dengan JEOL JSM-6510LA yang dilengkapi dengan perangkat Energy Dispersive X-Ray Spectroscopy (EDS) untuk analisis komposisi kimia. Metode Secondary Electron (SE) dan Backscattered Electron (BSE) dengan opsi Low-Vacuum dilakukan untuk mendapatkan kontras yang optimal. Hasil analisa menunjukan bahwa pada kedua sampel telah tumbuh lapisan oksida berupa $\mathrm{ZrO}_{2}$ dengan ketebalan maksimal 2.4 dan $3.5 \mathrm{~mm}$ untuk masing-masing temperatur 500 dan $700{ }^{\circ} \mathrm{C}$. Gambar BSE telah menunjukan batas lapisan dengan jelas, tidak memberikan ruang untuk interpretasi ganda.
\end{abstract}

Kata kunci: SEM, EDS, SE, BSE, lapisan oksida, paduan zirkonium, mikrostruktur.

\begin{abstract}
SCANNING ELECTRON MICROSCOPY STUDIED TO CHARACTERIZE OXIDATION PROCESS OF ZIRCONIUM ALLOY. Scanning Electron Microscopy study has been performed in order to characterize the microstructure of oxide layers formed on the Zirconium alloy which is believed as the most prospective material for fuel cladding of nuclear reactor 4th generation and modern fusion reactor. With help of the SEM analytical methods, the investigation is aimed to get detail information that is important for understanding the oxidation process on Zirconium alloy at high temperatures. The samples used are Zirconium alloy nugget composed of $96.9 \mathrm{wt} . \% \mathrm{Zr}, 2.5 \mathrm{wt} . \% \mathrm{Nb}, 0.5 \mathrm{wt} . \% \mathrm{Mo}$ dan 0.1 wt.\%Ge and are subjected to the MSB test at 500 and 700 oC. SEM JEOL JSM-6510LA equipped with Energy Dispersive XRay Spectroscopy (EDS) for chemical analysis was used. Secondary Electron (SE) and Backscattered Electron (BSE) with Low-Vaccum option has been applied to get sufficient image contrast. The results showed on both samples oxide layers have been grown which is indicated as ZrO2 with maximum thickness 2.4 and $3.5 \mu \mathrm{m}$ for temperatures 500 and $700 \mathrm{oC}$ respectively. BSE image revealed clearly the boundary of the oxide layer and matrix and left no dual interpretation.
\end{abstract}

Keywords : SEM, EDS, SE, BSE, oxide layer, zirconium alloy, microstructure. 


\section{PENDAHULUAN}

Dalam beberapa tahun terakhir ini, penelitian dan pengembangan paduan zirkonium dengan tambahan elemen-elemen $\mathrm{Nb}$, Mo dan Ge dalam jumlah kecil khusus untuk material kelongsong bahan bakar nuklir telah dikembangkan di PSTBM-BATAN [13]. Salah satu parameter dan persyaratan terpenting pada bahan kelongsong yang perlu diteliti adalah ketahanan material terhadap korosi yang disebabkan proses oksidasi pada suhu tinggi, terlebih dalam kondisi kecelakaan dengan banyak kehilangan air pendingin (LOCA), situasi dengan integritas pembangkit nuklir harus tetap terjaga. Pada kondisi operasi suhu tinggi ketahanan oksidasi material yang baik ditentukan oleh kemampuan material dalam membentuk lapisan oksida yang dapat melindungi bahan dari proses oksidasi berlanjut atau bahkan kehancuran material yang dikenal dengan istilah Breakaway [4]. Oksidasi temperatur tinggi merupakan proses kimia yang terjadi dalam skala mikroskopik. Proses pembentukan fasa oksidasi berikut fenomena yang menjadi ciri khas-nya seperti epitaxy, spinnel, dan metastability terjadi dalam ukuran yang lebih kecil dari panjang gelombang cahaya terlihat [5].

Teknik karakterisasi konvensional yang berbasis pada panjang gelombang $650 \mathrm{~nm}$ keatas, seperti mikroskop optik pada analisis metalografi tidakmemiliki resolusi yang cukup untuk mendapatkan informasi ilmiah yang diharapkan. Oleh karena itu diperlukan metode identifikasi dan karakterisasi lain yang dapat memberikan resolusi yang lebih tinggi sehingga dapat memberikan bantuan "penglihatan" bagi para peneliti untuk dapat mengamati apa yang terjadi di dalam dan sekitar interface antara bahan dengan lapisan oksida secara detil atau bahkan secara In-Situ. Untuk keperluan tersebut, Scanning Electron Microscopy (SEM) dipahami sebagai teknik yang sesuai yang diterima dan diakui oleh komunitas peneliti material dunia, ini ditandai dengan diberikannya penghargaan Nobel terhadap para penemunya, Ernst Ruska dan Max Knoll.

Identifikasi struktur mikro lapisan oksida dengan menggunakan SEM tidaklah sekedar pengambilan gambar dan fotografi, tetapi harus dilakukan dengan teknik dan metode operasi yang benar mengingat proses pembentukan image pada alat ini merupakan proses fisika yang merupakan interaksi korpuskular antara elektron sumber dengan atom pada bahan. Meskipun sinyal data yang dihasilkan cukup kuat dibanding mikroskop optik atau XRD, tetapi karena seringkali obyek pengamatan yang terbilang kecil dan mengandung komponen non konduktif, seperti lapisan pasivasi oksida pada permukaan, SEM dapat memberikan kontras yang relatif rendah terlebih pada perbesaran tinggi. Oleh karena itu SEM harus dioperasikan dengan pengaturan parameter elektron seperti high voltage, spot size, bias dan beam current juga parameter optik seperti kontras, fokus dan astigmatismus yang tepat sehingga diperoleh hasil gambar yang optimal secara ilmiah dan tidak memberikan interpretasi ganda. Selain itu, proses pengambilan gambar dan analisis kimia dengan SEM sangatlah dipengaruhi oleh jenis sampel berikut cara penangannya serta teknik preparasinya disamping kemampuan operasional dari operator nya.

Dalam makalah ini diuraikan hasil analisis dan karakterisasi sampel uji oksidasi pada temperatur tinggi dengan menggunakan SEM, yaitu material paduan zirkonium yang dikembangkan untuk pembuatan kelongsong bahan bakar nuklir. Analisis ini terutama ditujukan guna mendapatkan informasi mengenai sejauh mana SEM dapat menjawab tentang fenomena apa yang terjadi pada proses oksidasi, berikut kekurangannya.

\section{METODE}

\section{SEM}

Dalam Gambar 1 adalah skema diagram standar SEM JSM-6510LA dari fabrikan JEOL yang digunakan dalam penelitian ini dengan fasilitas analisis komposisi kimia berupa detektor sinar X. Komponen utama alat SEM ini pertama adalah tiga pasang lensalensa elektromagnetik yang berfungsi memfokuskan berkas elektron menjadi sebuah titik kecil, lalu oleh dua pasang scan coil discan-kan dengan frekuensi variabel pada permukaan sampel. Semakin kecil berkas difokuskan semakin besar resolusi lateral yang dicapai. Kesalahan fisika pada lensa-lensa elektromagnetik berupa astigmatismus dikoreksi oleh perangkat stigmator. SEM tidak memiliki sistem koreksi untuk kesalahan aberasi lainnya. 
Yang kedua adalah sumber elektron, biasanya berupa filamen dari bahan kawat tungsten atau berupa jarum dari paduan Lantanum Hexaboride LaB6 atau Cerium Hexaboride CeB6, yang dapat menyediakan berkas elektron yang teoretis memiliki energi tunggal (monokromatik), Ketiga adalah imaging detector, yang berfungsi mengubah sinyal elektron menjadi gambar/image. Sesuai dengan jenis elektronnya, terdapat dua jenis detektor dalam SEM ini, yaitu detektor SE dan detektor BSE.

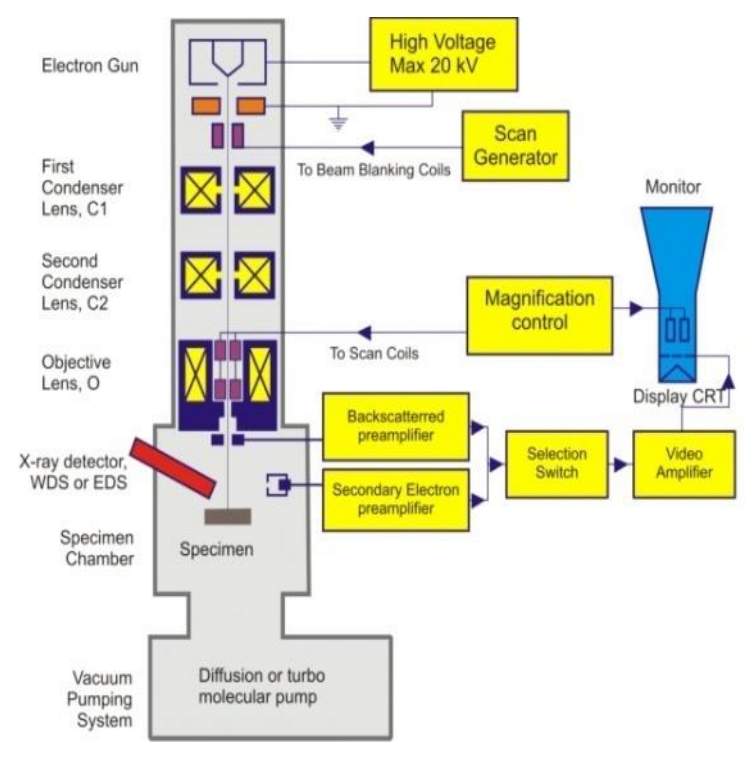

Gambar 1. Blok diagram SEM.

Untuk menghindari gangguan dari molekul udara terhadap berkas elektron, seluruh jalur elektron (column) divakum hingga $10^{-6}$ torr. Tetapi kevakuman yang tinggi menyebabkan naiknya sensitifitas pendeteksian alat terhadap non-konduktifitas, yang menyulitkan analisis pada bahan bahan non-konduktif, seperti keramik dan oksida. Untuk mengatasi hal tersebut SEM ini memiliki opsi untuk dapat dioperasikan dengan vakum rendah, yang disebut LowVaccum Mode. Dengan teknik low vaccum kita dapat menganalisis bahan yang non konduktif sekalipun. Tekanan pada mode ini berkisar antara 30 hingga $70 \mathrm{~Pa}$.

\section{Interaksi bahan dan elektron}

Ketika berkas elektron discan pada permukaan sampel, terjadi interaksi elektron dengan atom-atom di permukaan maupun di bawah permukaan sampel. Seperti terlihat pada Gambar 2, akibat interaksi tersebut sebagian besar berkas elektron berhasil keluar kembali, elektron-elektron tersebut disebut sebagai Backscattered Electrons (BSE), sebagian kecil elektron masuk ke dalam bahan kemudian memindahkan sebagian besar energi pada elektron atom sehingga terpental ke luar permukaan bahan, yaitu Secondary Electrons (SE). Pembentukan elektron-elektron sekunder selalu diikuti proses munculnya X-ray yang karakteristik untuk setiap elemen, sehingga dapat digunakan untuk mengukur kandungan elemen yang ada di dalam bahan yang diteliti.

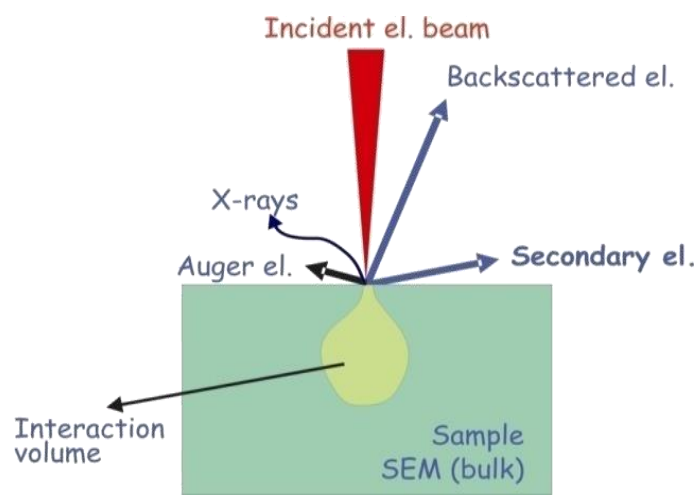

Gambar 2. Skema interaksi antara bahan dan elektron di dalam SEM.

Proses pembentukan BSE terjadi pada atom-atom di bagian permukaan sampel yang lebih dalam. Ini disebabkan tumbukan antara elektron dari sumber dengan inti atom, seperti ditunjukan pada Gambar 3. Karena massa proton yang membentuk inti hingga 2000 kali lebih besar dari elektron, maka setiap tumbukan akan menyebabkan terpentalnya sebagian besar elektron ke arah $180^{\circ}$. Artinya, sebagian akan dipantulkan kembali ke arah di mana mereka datang yaitu ke luar permukan bahan. Elektron-elektron BSE ini membawa informasi tentang atom-atom yang ditumbuknya beserta ikatannya dalam fasa. Sehingga kontras pada image yang terbentuk dari elektron-elektron BSE dalam batas-batas tertentu dapat dipandang sebagai kontras fasa.

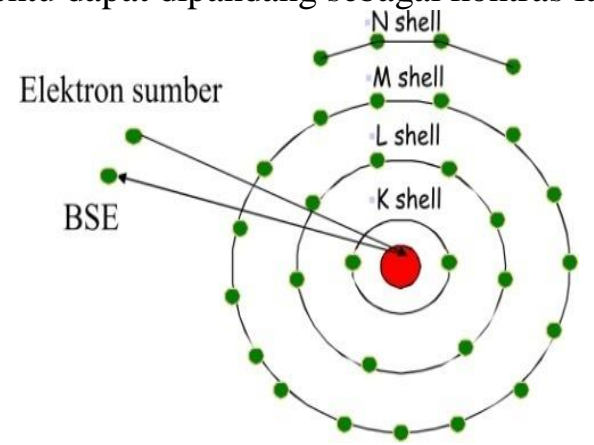

Gambar 3. Proses terbentuknya BSE. 
Jika elektron sumber dalam perjalanannya di dalam bahan hanya melewati awan elektron atau orbital sebuah atom maka elektron tersebut dapat saja memindahkan sebagian energi kinetiknya kepada satu atau lebih elektron pada orbit tersebut. Elektron itu akan menjadi tidak stabil dan dalam kondisi tereksitasi sehingga meninggalkan posisinya dan keluar dari permukaan bahan, maka elektron tersebut dikenal sebagai secondary electron (SE) atau elektron sekunder, Gambar 4. Karena elektron-elektron SE memiliki energi yang rendah, maka hanya elektronelektron yang berada atau sangat dekat permukaan bahan saja yang dapat lolos ke luar. Dengan bantuan detektor khusus elektron SE dapat dimanfaatkan untuk membentuk image morfologi permukaan bahan dengan baik. Struktur permukaan berikut ciri-cirinya, seperti batas butir, edge, porositas, puncak atau lembah akan terlihat lebih detil dengan resolusi yang lebih tinggi dibanding BSE.

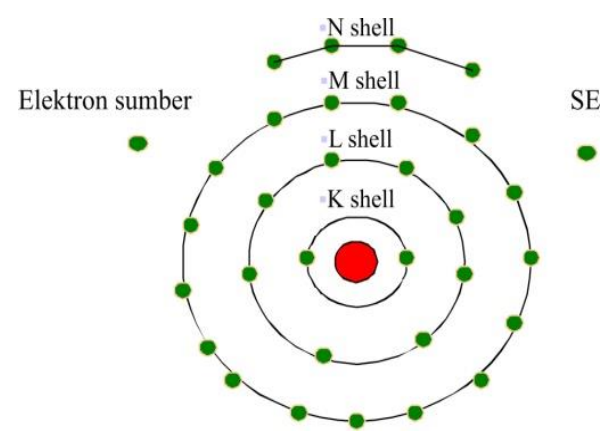

Gambar 4. Proses pembentukan SE dan X-ray.

\section{Eksperimen}

Pengujian SEM dilakukan pada sampel ingot paduan zirkonium $\mathrm{ZrNbMoGe}$ untuk kondisi sebelum dan sesudah uji oksidasi suhu tinggi dengan Mass Suspension Balance (MSB). Uraian tentang MSB dapat dilihat pada publikasi [6-7]. Bahan paduan dibuat dengan teknik peleburan di dalam arc melting furnace dengan komposisi dalam persen berat adalah $96,9 \% \mathrm{Zr}, 2,5 \% \mathrm{Nb}, 0,5 \%$ Mo dan $0,1 \%$ Ge dengan spesifikasi seperti ditunjukkan pada Tabel 1.

\section{Preparasi Sampel}

Untuk keperluan analisis SEM, sampel ingot dan sampel rol dipersiapkan sesuai prosedur preparasi sampel padatan yang dikembangkan di PSTBM. Pertama-tama sampel dipotong masing-masing dengan ukuran $2 \times 2 \mathrm{~cm}$ dengan menggunakan diamond blade cutter tipe $J M Q-12$ pada kecepatan rendah untuk menjamin permukaan potongan yang rapi dan bersih dari gram. Kemudian salah satu permukaan kedua sampel di amplas (grinder) pada mesin poles MoPao 2D Grinder Polisher dengan kertas amplas dengan urutan kekasaran berturut-turut dari 120, 400, 800, 1200 hingga 2000. Kegiatan ini diakhiri dengan memoles sampel pada permukaan kain bludru dan diamond pasta $0,25 \mu$ yang diperlukan untuk meminimalisir jejak goresan serta menghilangkan partikel karbida yang lepas dari kertas amplas. Proses selanjutnya adalah etsa permukaan, proses ini bertujuan untuk melarutkan dan membersihkan lapisan pasivasi yang terbentuk selama proses pengamplasan dan polising yang biasanya terdiri dari lapisan sangat tipis oksida metal yang sangat keras.

Tabel 1. Spesifikasi sampel uji.

\begin{tabular}{cc}
\hline $\begin{array}{c}\text { Jenis/ } \\
\text { kode } \\
\text { Sampel }\end{array}$ & Keterangan sampel \\
\hline $\begin{array}{c}\text { Standar } \\
\text { (S1) }\end{array}$ & $\begin{array}{c}\text { Ingot Paduan ZrNbMoGe, hasil } \\
\text { peleburan dengan tungku busur } \\
\text { listrik. }\end{array}$ \\
$\begin{array}{c}\text { Oksidasi } \\
\text { (S500) }\end{array}$ & $\begin{array}{c}\text { Ingot paduan ZrNbMoGe yang } \\
\text { telah dioksidasi dengan udara } \\
\text { pada suhu 500 }{ }^{\circ} \mathrm{C} \text { selama 5jam. }\end{array}$ \\
$\begin{array}{c}\text { Oksidasi } \\
\text { (S700) }\end{array}$ & $\begin{array}{c}\text { Ingot paduan ZrNbMoGe yang } \\
\text { telah dioksidasi dengan udara } \\
\text { pada suhu } 700{ }^{\circ} \mathrm{C} \text { selama 5jam. }\end{array}$ \\
\hline
\end{tabular}

Kegiatan etsa dilakukan menggunakan larutan Nital 3\%. Larutan ini dibuat dari campuran $3 \mathrm{ml}$ asam nitrat $\mathrm{HNO}_{3}$ dengan 97 $\mathrm{ml}$ metanol teknis. Proses etsa terjadi dalam waktu maksimal 20 detik, hingga permukaan sampel yang mengkilap berubah menjadi dob. Itu pertanda bahwa permukaan telah terlarut dalam nital. Untuk menjamin tidak terjadi etsa susulan akibat larutan nital yang tertinggal pada pori-pori permukaan sampel, setelah etsa sampel dicelupkan ke dalam metanol lalu di aduk. Tegangan permukaan yang terjadi pada kontak antara metanol dan permukaan dapat membersihkan larutan etsa yang tersisa dengan sempurna. Kemudian sampel di bersihkan dengan air. Terakhir dilakukan pengeringan menggunakan Hair Dryer pada suhu ruang hingga benar-benar kering dan tidak meninggalkan kelembaban yang dapat 
mengganggu proses pemvakuman di dalam ruang sampel pada SEM yang pada akhirnya akan mengkontaminasi lensa elektromagnetik akibat molekul-molekul air yang terbawa.

\section{Langkah dan Parameter Pengujian}

Untuk proses pengambilan gambar (image) dan data komposisi sampel teroksidasi dengan alat SEM, sampel diletakkan dan ditempel di atas SEM specimen holder dengan menggunakan carbon double tipe dengan bagian penampang lintang (cross section) mengarah vertikal ke atas atau lensa obyektif. Agar susunan lapisan matriks bahan dengan lapisan oksida terlihat dengan jelas. Double tip ini terbuat dari bahan karbon yang konduktif di dua sisi yang berfungsi menghantarkan semua elektron yang masuk ke dalam sampel keluar melalui grounding.

Ruang sampel divakum hingga $10^{-6}$ torr untuk menjamin bahwa kolom SEM bebas dari molekul udara. SEM dioperasikan dengan standar parameter operasi sebagai berikut:

$\begin{array}{ll}\text { High Voltage } & : 20 \mathrm{kV} \\ \text { Spot Size } \quad: 50 & \\ \text { Work Distance(WD) } & : 10 \mathrm{~mm}\end{array}$

WD setinggi $10 \mathrm{~mm}$ dipilih sebagai kompromi terhadap setingan untuk akuisisi sinyal EDX yang mensyaratkan $10 \mathrm{~mm}$ agar pendeteksian X-Ray dan pencacahannya optimal.

\section{HASIL DAN PEMBAHASAN}

\section{ZrNbMoGe standar}

Hasil SEM untuk uji struktur mikro pada sampel paduan $\mathrm{ZrNbMoGe}$ standar tampak atas ditunjukkan pada Gambar 5. Image diambil dengan detektor SE.

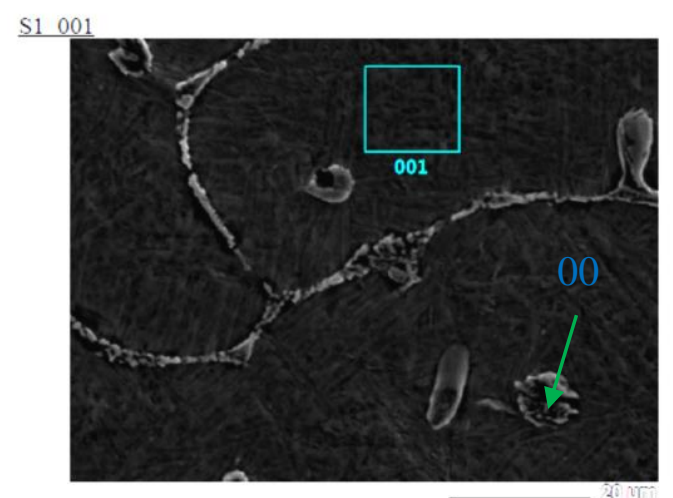

Gambar 5. Struktur mikro ZrNbMoGe standar.
Dari gambar terlihat bahwa sampel ini memiliki mikrostruktur terdiri dari fasa martensite dan sedikit bainite dengan struktur lancette yang khas. Dapat terlihat dengan jelas presipitasi fasa kedua di dalam dan batas butiran. Kedudukan fasa kedua ini lebih tinggi dari matriks, menunjukan sifatnya yang lebih keras dibanding bahan dasarnya. elama proses pemolesan maupun proses etsa keduanya mengalami tingkat erosi yang berbeda. Dari hasil EDS yang diambil dengan dead time $40 \%$ dan sudut akuisisi sekitar $15^{\circ}$ serta jumlah pencacahan total 2500 counts, diketahui bahwa presipitasi tersebut adalah fasa $\mathrm{Zr}-\mathrm{Ge}$ dengan kandungan masing-masing 89 dan $1 \%$ berat, lihat Gambar 6.

Jika memperhitungkan persen atom dan mengabaikan kehilangan sinyal akibat absorpsi dan efisiensi akusisi detektor SiLi EDX, maka dapat diperkirakan rumus kimia fasa tersebut adalah $\mathrm{Zr}_{55.54} \mathrm{Ge}_{0.8}$. Penulis menyangsikan eksistensi elemen Mo dalam presipitasi, karena kedua peak Mo dalam spektrum tidak definitif dan di bawah background bahkan overlaping dengan sinyal $\mathrm{K}_{\beta}$ dari elemen $\mathrm{Zr}$ yang sangat tinggi. Dugaan ini divalidasi dengan hasil perhitungan program.

Unsur Karbon C dipastikan berasal dari lemak akibat penanganan dan cracking molekul $\mathrm{CO}_{2}$ dan uap oli pompa vakum yang mungkin akibat adanya fine leckage masuk ke dalam kolom dalam jumlah yang sangat kecil. Meskipun jumlah kandungannya di dalam campuran mencapai $2.5 \%$, unsur Niobium tidak terdeteksi dengan EDS. Hal ini kemungkinan disebabkan oleh inhomogenitas yang terjadi selama proses pelelehan saat pembuatan nugget paduan. Analisis X-ray Diffration (XRD) diharapkan dapat memverifikasi atau menggagalkan dugaan ini.

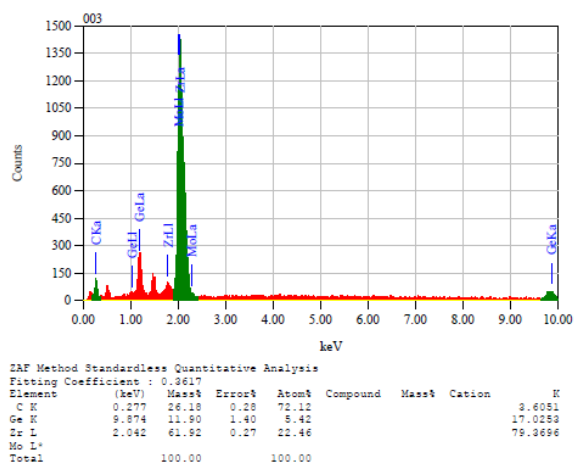

Gambar 6. EDS spektrum presipitasi Struktur mikro ZrNbMoGe standar 


\section{ZrNbMoGe setelah oksidasi}

Pada dua sampel paduan dilakukan uji oksidasi di dalam MSB pada temperatur masing-masing $500^{\circ} \mathrm{C}$ dan $700^{\circ} \mathrm{C}$ dalam udara ruang. Hasil MSB ditunjukan pada Gambar 7 sebagai pertambahan masa berdasarkan waktu pemanasan.

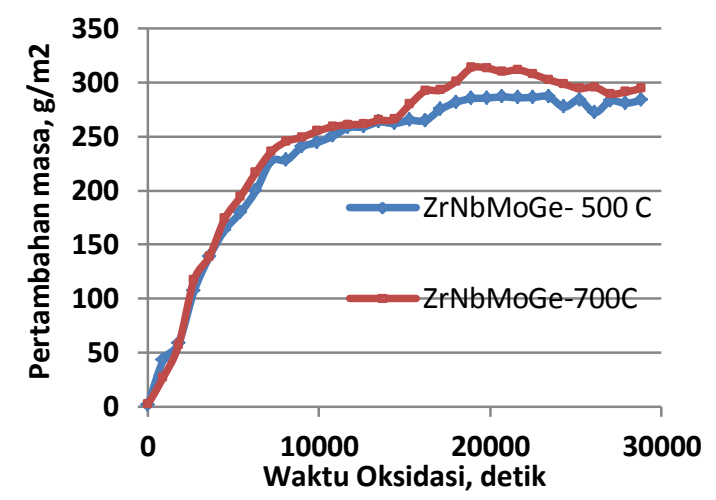

Gambar 7. Grafik perubahan masa oksidasi sampelpaduan $\mathrm{ZrNbMoGe}$.

Gambar 7 menunjukkan telah terjadi lapisan oksida di permukaan yang menjadi lapisan pelindung yang menentukan karakteristik oksidasi. Pertumbuhan berat menunjukan grafik yang naik turun atau bergelombang, hal ini disebabkan karena selama proses oksidasi terjadi pertumbuhan dan pelepasan (flaking) lapisan oksida secara lokal. Untuk mendukung analisis oksidasi tersebut dilakukan uji SEM untuk mengamati mikrostruktur lapisan oksida serta kemungkinan mengungkap proses yang terjadi selama oksidasi. Oleh karena itu pengujian SEM ini diarahkan untuk mengamati terbentuknya lapisan oksida pada permukaan sampel paduan.

Gambar 8 menunjukkan penampang lintang sampel paduan setelah oksidasi pada temperatur $500{ }^{\circ} \mathrm{C}$ diambil dengan detektor BSE. Seperti telah dibahas pada bagian teori pembentukan image di atas, terlihat perbedaan kontras yang jelas antara matriks dengan lapisan oksida di permukaan. Bagian atas yang untuk sementara diasumsikan sebagai lapisan oksida menunjukan kesan warna gelap, sedangkan matriks di bawahnya berwarna terang. Analisis pembentukan sinyal BSE mengindikasikan bahwa bagian matriks memiliki densitas yang lebih besar atau adalah fasa dengan susunan atom yang lebih berat dari bagian lapisan atas.

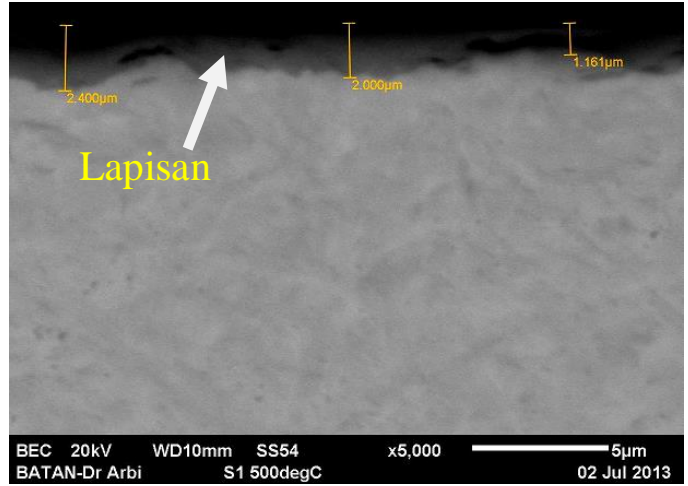

Gambar 8. Struktur mikro matrik dan lapisan oksida paduan $\mathrm{ZrNbMoGe}$ setelah oksidasi $500{ }^{\circ} \mathrm{C}$.

Akusisi spektrum EDS pada Gambar 9 memberikan verifikasi bahwa lapisan bagian atas merupakan oksida $\mathrm{Zr}-\mathrm{O}$. Hal ini bersesuaian dengan hasil image BSE, karena densitas $\mathrm{Zr}-\mathrm{O}$ lebih rendah dari pada paduan $\mathrm{ZrNbMoGe}$

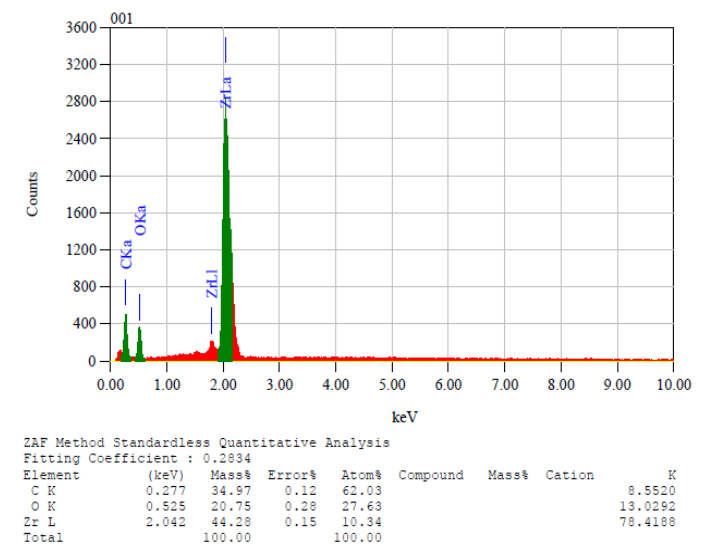

Gambar 9. Hasil Uji EDS ZrNbMoGe setelah oksidasi $500{ }^{\circ} \mathrm{C}$.

Berdasarkan komposisi unsur hasil perhitungan sprektrum EDS pada Gambar 9 unsur dominan $\mathrm{Zr} 44.28 \%$ dan $\mathrm{O} 20.75 \%$ dapat diperkirakan bahwa lapisan tersebut adalah oksida $\mathrm{ZrO}_{2}$ sesuai dengan analisis dalam proses oksidasi. Untuk mengetahui ketebalan oksida yang terbentuk yang merupakan faktor penting dalam menunjang ketahanan oksidasi material, dilakukan pengukuran tebal oksida. Hasil pengukuran ketebalan oksida pada Gambar 3a. menunjukkan ketebalan oksida yang bervariasi antara 1,2 sampai $2,4 \mu \mathrm{m}$.

Untuk pengujian SEM pada sampel $\mathrm{ZrNbMoGe}$ yang dioksidasi pada suhu $700{ }^{\circ} \mathrm{C}$ dengan dilakukan uji struktur mikro dan lapisan oksida seperti pada oksidasi $500^{\circ} \mathrm{C}$. 
Hasil uji untuk oksidasi pada suhu $700^{\circ} \mathrm{C}$ ditunjukkan pada Gambar 10 dan 11 diambil dengan detektor BSE.

Dari sisi morfologi sampel ini menunjukan kemiripan dengan sampel setelah oksidasi pada $500{ }^{\circ} \mathrm{C}$, perbedaannya terlihat dari ketebalan lapisan oksida pada sampel dengan oksidasi pada temperatur $700{ }^{\circ} \mathrm{C}$. Ketebalan oksida yang terukur adalah antara $2,4 \mu \mathrm{m}$ sampai dengan $3,6 \mu \mathrm{m}$.

Dari spektrum komposisi unsur pada Gambar 11. dengan unsur dominan 57,77\% $\mathrm{Zr}$ dan $22,78 \% \mathrm{O}$ menunjukkan terbentuknya lapisan oksida $\mathrm{ZrO}_{2}$.

Lapisan oksida yang lebih tebal menunjukkan laju oksidasi yang lebih tinggi pada kenaikan suhu oksidasi seperti dijelaskan dalam analisis ketahanan oksidasi.

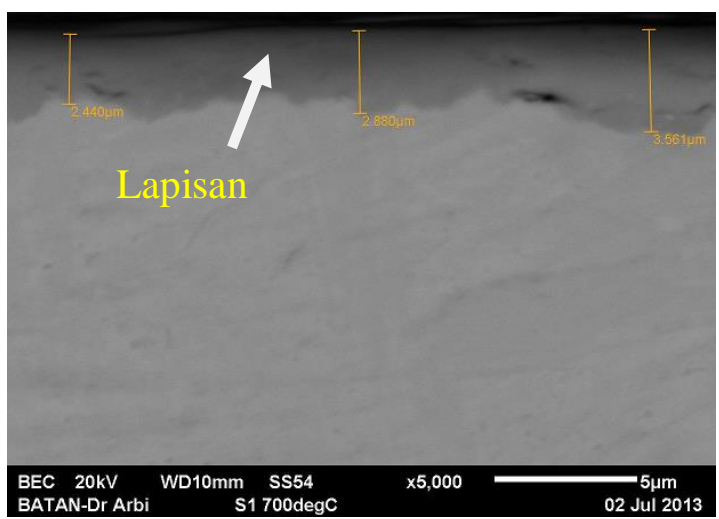

Gambar 10. Struktur mikro matrik dan lapisan oksida paduan $\mathrm{ZrNbMoGe}$ setelah oksidasi $700{ }^{\circ} \mathrm{C}$.

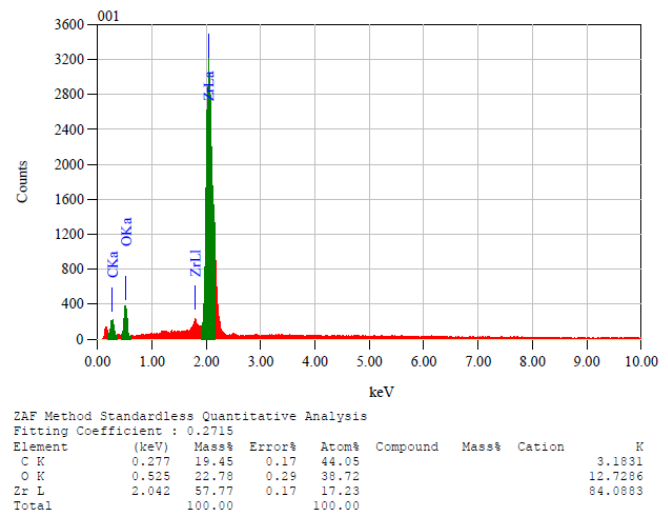

Gambar 11. Hasil Uji EDS ZrNbMoGe setelah oksidasi $700^{\circ} \mathrm{C}$.

\section{KESIMPULAN}

Pengujian SEM menghasilkan gambar mikrostruk- tur dan komposisi unsur kimia dalam paduan material. Lapisan oksida hasil oksidasi paduan zirkonium juga dapat terdeteksi dengan jelas menggunakan detektor BSE. Hasil uji EDS dapat digunakan untuk memprediksi fasa yang terjadi setelah oksidasi serta dapat mendukung hasil analisis karakteristik dan ketahanan oksidasi material paduan.

\section{DAFTAR PUSTAKA}

1. Parikin, Bandriyana, A. H. Ismoyo, Effects of adding $\mathrm{Cu}$ element on the crystal structure of $\mathrm{ZrNbMoGe}$ alloys, Conference of Nuclear Technology, Center for Technology of Accelerator and Material Process (2013), 103-108.

2. Bandriyana, D. H. Prajitno, A. Dimyati, Effect of Copper Addition on High Temperature Oxidation of Zirconium Alloy ZrNbMoGe for Advanced Reactor Fuel Cladding Material, Adv. Mat. Research, Vol. 896 (2014) 617-620.

3. Parikin, A. Fajar, Ismoyo A.H., Bandriyana, Neutron diffraction technique on the structural identification of $\mathrm{ZrNbMoGe}$ alloy, Proceedings of The International Conference on Materials Science and Technology (2011) 91-97.

4. Quadakkers, W.J., Naumenko, D., Dani, M., Dimyati, A., Mayer, J., and Singheiser, L., Importance of Reactive Element Interaction with $\mathrm{C}$ - and $\mathrm{N}$ impurities for Alumina Scale Growth and Adherence on FeCrAl Alloys, John Stringer Symposium, ASM Conference Indianapolis (2001) 2025.

5. Mayer, J., Penkalla, H.-J., Dimyati, A., Dani, M., Untoro, P., Naumenko D., and Quadakkers, W.J., Time dependence of $\mathrm{Mg}$-incorporation in alumina scales on $\mathrm{FeCrAl}$ alloys studied by FIB-prepared TEM cross sections, The Fifth International Conference on the Microscopy of Oxidation (2002) 167-173.

6. Untoro, P., and Wagiyo, Workshop on High Temperature Corrosion Using TGA/MSB, National Nuclear Energy Agency (BATAN), Serpong (2002).

7. www.ankersmid.com/china/physic/ch arasterisa-tion/products/rubotherm 